\title{
Drafting nuclear weapons
}

I would like to the opportunity to address some of the contemporary problems in public health and human rights that evolved from my early training in engineering. The point of this letter is to examine the relationship of engineering and scientific education to the wider context of international conflicts and the risk of war.

In the 1950s I studied engineering at Brooklyn Technical High School - an all-boys public school with 5000 students and one of the best secondary schools in America. At that time I was undecided as to which branch of engineering I would go into - but Brooklyn Tech was the perfect place for developing these skills and interests. Many Tech students had very useful hands-on experience with this hardware and related machinery. I graduated from Brooklyn Tech in 1957 and was admitted to the School of Engineering at the City College of NY - one of the top public high schools in the US - which (like Tech) was tuition-free back then.

My experience was based on that of my family in New York Citywhere my brother and father were both engineering professionals. My father was a master machinist for ITT in New Jersey and, while we lived in Brighton Beach Brooklyn, he had worked during WW 2 in large factory plants and machine shops for the development and production of engineering equipment and military weapons. My older brother had completed Brooklyn Tech six years earlier, and also attended Brooklyn PolyTech - a science and engineering college of NYC. He worked for various engineering and design job-shops and later ran a company which employed me as a draftsman. Starting with my junior year at Tech. I worked at well-paid drafting jobs after school and in the summers, which enabled me to be financially selfsufficient. This included building-design and construction, aviation sciences, and automotive design and function.

While we had no experience at Brooklyn Tech High School in any training with military weapons, our academic course-work frequently involved discussions of the history of the 20th century wars, which so many of that generation had served in. I would later learn that Fort Greene - a city Park adjacent to Tech - had a tall concrete monument, which was the funeral site for over 10,000 Americans who had died in the American Revolutionary War. Many of them died from contagious diseases that struck those taken prisoner by the British and imprisoned in the crowded holds of prison ships anchored in NY Harbor during that war. My father often brought home photo books and magazine articles about World War II, and he became my role model because his work in engineering helped us to win the war against Hitler and the Japanese.

While I had no first-hand experience with military weapons during this period, our academic course-work frequently involved discussions of America's past wars. At that time (the 1950's) it also became evident that modern military force was connected to nuclear weapons: the US had been the first nation to use nuclear bombs to defeat our enemy Japan at war. In the decades after World War II many nations competed to produce an array of missiles incorporating nuclear weapons and we were all exposed to a visible face of nuclear weapons.

Like all public school students in New York City, I was also routinely exposed to the "duck and cover" exercises of the classroom to address the risk of nuclear war. There was a place for this within
Volume 9 Issue I - 2020

\author{
Ernest Drucker \\ Emeritus Professor of Family and Social Medicine, Montefiore \\ Medical Center,Albert Einstein College of Medicine, USA
}

\section{Correspondence: Ernest Drucker, PhD, Emeritus Professor of Family and Social Medicine, Montefiore Medical Center, Albert Einstein College of Medicine, USA, Email emdrucker@earthlink.net}

Received: January 26, 2020 | Published: February 28, 2020

most school classes, which involved getting under our desks and pulling down the paper shades over the classroom windows to protect us from the shattered glass of a nuclear attack - all of which was clearly useless given the huge destructive realities of nuclear weapons. These exercises were done during the postwar period by the kid's teachers and organized by the NY City Board of Education. In response to the threats of nuclear weapons and war in this era (most of that involving the Soviet Union) our classes also included movies of nuclear bombs going off in the midst of naval fleets, pictures of nuclear weapons blowing apart buildings large and small, and (often on TV) mind-blowing images of the detonation of huge Hydrogen bombs on Pacific islands. After World War II, the Cold War with the Russians included this dramatic exposure to atomic weapons for those of us growing up at that time.

This period also coincided with the introduction of television on a large scale into American homes, which spent a lot of its time showing films of the past WW2 that had just ended and the carryover of the nuclear weaponry to the present time - and later included news of the Korean War in the 1950s, which had frequent threats of nuclear weapons, with many images about the looming threats of nuclear war. We then had a series of popular Hollywood films about atomic weapons and war in that period. One of the greatest was Dr. Strangelove or "How I Learned to Stop Worrying and Love the Bomb", a1964 film that satirizes the Cold War fears of a nuclear conflict between the Soviet Union and the United States. This British film was produced, directed, and co-written by Stanley Kubrick, with stars Peter Sellers, George C. Scott, Sterling Hayden and Slim Pickens - based on Peter George's (1958) novel Red Alert. The story concerns an unhinged United States Air Force general who orders a first strike nuclear attack on the Soviet Union. It follows the President of the United States, his advisors, the Joint Chiefs of Staff, and a Royal Air Force (RAF) officer as they try to recall the bombers to prevent a nuclear apocalypse. It separately follows the crew of one B-52 bomber as they try to deliver their payload. In 1989, the United States Library of Congress included Dr. Strangelove in the first group of films selected for preservation in the National Film Registry.

Back then I was preparing myself for earning a living as a draftsman. New York's public school system set the stage for my professional 
plans and subsequent decisions about a career in engineering. At the heart of the academic program I took at Brooklyn Tech was four years of courses in the major components of all engineering disciplines and the basic sciences behind them. I had always enjoyed technical drawing and Tech High School had provided four years of occupational training as a draftsman.

While at City College I worked in various after-school drafting jobs in New York and, in the summers, I went for jobs out of town. In 1960, the year Jack Kennedy became president, I worked at Western Electric in North Carolina, and at a drafting shop in Florida run by Martin Aeronautics near Orlando - working at a factory which designed and built guided missiles. One specific job I had was doing drafting of wiring diagrams for these missiles - one of which was the then- new Pershing missile - an early sophisticated anti-missile weapon. The wiring diagrams for these missiles were based on a set of pencil and ink sketches by the design engineers which I had to draw to prepare for their publication onto printed pages. This was all occurring years before the invention of computerized drafting tools and equipment. My job was to transcribe these free-hand engineers designs into pen and ink images on paper or printable master pages for transparent plastic sheets - that would often incorporate the engineers designs and data into publishable forms for use in the real world.

At this time I was living with my brother and his family near Orlando and working in Central Florida, right next to the test site for these weapons at Cape Canaveral - later Cape Kennedy. From that vantage point I had the opportunity to see test launches of many different kinds of rockets and missiles - including some of the early manned space flights that the US was doing- most famously as part of NASA. Later I focused on the flight operation of these missiles, which in their real-life presence, made a big impression on me because of their enormous power and potential destructiveness, that was not so evident from my history of drafting their blueprints and seeing them built on an assembly line. That was only part of the story - the rest had to do with the details of the weaponry these missiles carried - which was also part of the drafting requirement for the wiring diagrams.

One feature of the drafting job that caught my attention was the presence of a small blank box on most of the pages given to us for the wiring diagrams of these missiles. They were labeled as the "Sandia Box". Sandia National Laboratory in Albuquerque New Mexico was a major player in the development of missiles and nuclear weapons in the post World War II period. Sandia is a Federal "multi-mission laboratory" managed and operated under contract of the U.S. Department of Energy's National Nuclear Security Administration. At the time I had no idea what that implied but later learned that the Sandia box was the place where all the wiring diagram components converged to show the links between the mechanical and electrical features of the missile and its nuclear weapons. Throughout this period of the early 1960's I was able to get drafting jobs during college doing drafting in different kinds of factories that did design and drafting work for a wide spectrum of industries - most powerfully those of the defense industry. It was there that I was introduced to the fact that the drafting we would be doing was related to the creation and employment of nuclear weapons - indeed all of the drawings that I did for one particular summer the job was on wiring diagrams for nuclear armed missiles.

\section{Drafting nuclear weapons}

The nuclear weapons enterprise was being developed through several major eras of The Cold War. These included Design, Development, and Testing of increasingly sophisticated weapons and more precise delivery systems; Stockpile Stewardship and development of increasingly sophisticated tools to meet the challenge of preserving the aging stockpile in the absence of nuclear explosives testing (their last test was Sept.1992). This work included major diagnostic tools to develop advances in supercomputers for modeling and simulation, enabling virtual testing of atomic stockpile weapons. Sandia's Modernization work also played a key role in the principle of extended deterrence. President Obama, in his 2009 Prague speech, "A World Without Nuclear Weapons," described his vision for a reduced role for nuclear weapons in the U.S. national security policy. He stated that "as long as these weapons exist, the United States will maintain a safe, secure and effective arsenal to deter any adversary, and guarantee that defense to our allies." My drafting experience on guided missiles and the fact of their carrying nuclear weapons totally altered my plans for an engineering career.

My own early work and political experiences all co-existed with the threat of nuclear war, which made me want to get out of engineering. Instead, throughout this period of the 1960s and afterwards, I was very active in Anti-War work related to the Vietnam war. To my surprise the politics of the day assumed a key place in my new career - where I worked as a peace activist . First off I was a founding student member of VVAW (Vietnam Veterans Against War). I next studied undergraduate psychology at City College with Prof. Kenneth Clark - a great African - American social psychologist dedicated to social justice and the growing peace movement. At this time I was active in a lot of the work of the world Peace Movement and its early years in the US. I became a founder of a group called Educators for Social Responsibility - an American teachers organization that took issues like nuclear war and racism as part of our professional development. Later, when the Vietman War ended (in April 1975) I taught undergrad Vietnam Vets in a Sociology course at Brooklyn College. Cold War issues dominated public discourse at this time and inevitably found their way into my drafting jobs.

\section{Acknowledgments}

None.

\section{Conflicts of interest}

None. 